\title{
Laboratory based study of undetectable thyroid stimulating hormone
}

\author{
M A POLLOCK, A JONES \\ From the Department of Clinical Biochemistry, Hope Hospital, Salford
}

SUMMARY The clinical importance of an undetectable thyroid stimulating hormone (TSH) concentration $(<0.2 \mathrm{mU} / \mathrm{l})$ was studied in a consecutive series of 2573 requests for routine thyroid function tests. Two hundred and seventeen $(8.4 \%)$ patients had an undetectable TSH concentration, and of these $39(18 \%)$ had otherwise normal thyroid hormone concentrations and no history of thyroid disease. In a follow up study 71 patients (34 outpatients and 37 inpatients) with undetectable TSH concentration associated with otherwise normal thyroid hormone concentrations were randomly selected during routine reporting of thyroid function test results. None of these patients had a history of thyroid disease. Sex hormone binding globulin concentrations were increased in five out of 50 of these patients and antithyroid antibodies were detectable in four out of 49, suggesting that in most cases the isolated undetectable TSH concentration was not associated with thyroid dysfunction, particularly hyperthyroidism. Isolated undetectable TSH concentration was observed in both inpatients and outpatients and was not associated with any particular clinical condition. Repeat specimens were received in 54 of the 71 patients and TSH concentration remained persistently undetectable in 35 of these.

Sensitive immunometric methods have been developed for measuring the concentration of serum thyroid stimulating hormone (TSH).$^{2}$ Many studies using such assays have shown that TSH is suppressed in hyperthyroidism and concentrations are clearly different from those in euthyroid subjects. ${ }^{3-5}$ On the basis of such studies it has been suggested that TSH by sensitive assay is suitable as a first line test of thyroid function. ${ }^{6}$ There have been some studies, however, in which undetectable TSH concentrations have been found in patients who did not have hyperthyroidism. $^{7-9}$.

During an analysis of a series of consecutive thyroid function tests sent to this laboratory several patients were observed with undetectable TSH concentrations associated with thyroxine $\left(\mathrm{T}_{4}\right)$ and tri-iodothyronine $\left(T_{3}\right)$ concentrations within the reference range. It was decided to identify a group of such patients during routine reporting of results and to request follow up specimens and detailed clinical information.

Sex hormone binding globulin (SHBG) concentration was measured in these patients in an attempt to clarify thyroid state as the concentration of this protein is increased in thyrotoxicosis. ${ }^{1011}$ Anti- microsomal and antithyroglobulin antibodies were also measured.

\section{Material and methods}

TSH was measured routinely by an in-house immunoradiometric assay (IRMA) using two monoclonal antibodies to TSH. Intrabatch coefficient of variation $(\mathrm{CV})$ was $<10 \%$ at $0.4-59 \mathrm{mU} / 1$ with a detection limit of $0.12 \mathrm{mU} / 1$ calculated using patient samples with low TSH concentrations, as described by Fraser and Wilde. ${ }^{12}$ Interbatch CV was $<10 \%$ in the concentration range $0.83-16 \mathrm{mU} / \mathrm{l}$. The reference range was $0.5-5.5 \mathrm{mU} / \mathrm{l}$ in euthyroid subjects $(\mathrm{n}=94)$.

TSH was also measured by the RIAgnost immunoradiometric assay TSH kit in specimens from several patients; the detection limit was $0.03 \mathrm{mU} / 1$ as calculated by the method of Fraser and Wilde. ${ }^{12}$ The lower limit of the reference range was $0.3 \mathrm{mU} / 1 \mathrm{ln}=$ 94) as determined in the DHSS sponsored evaluation of high sensitivity TSH assay kits. ${ }^{13}$ The RIAgnost kit was chosen as it showed the best performance in the DHSS sponsored evaluation. ${ }^{13}$

Serum $T_{4}$ and $T_{3}$ concentrations were measured by in-house radioimmunoassays and free $T_{4}$ by the Amerlex $M$ radioimmunoassay kit (reference ranges: $\mathrm{T}_{4} 50-150 \mathrm{nmol} / 1 ; \mathrm{T}_{3} 1 \cdot 0-2.9 \mathrm{nmol} / \mathrm{l} ;$ free $\mathrm{T}_{4} 9-26 \mathrm{pmol} /$ 1). 
Sex hormone binding globulin concentration was measured by an in-house IRMA (reference ranges: men 15-47 nmol/l; women 24-82 $\mathrm{nmol} / \mathrm{l}$ ). Antimicrosomal and antithyroglobulin antibodies were measured by Wellcome Thymune $\mathbf{M}$ and Thymune $T$ haemagluttination assay kits, respectively.

Initially a consecutive series of thyroid function test results on 2573 patients reported from the laboratory were analysed on the basis of the thyroid hormone concentrations and the clinical information given on the request form. In a subsequent study 71 other patients with suppressed TSH concentrations associated with otherwise normal thyroid function tests were randomly identified during routine reporting of results. A follow up specimen, together with detailed clinical information, were requested on these patients.

\section{Results}

The prevalence of an undetectable TSH concentration in 2573 thyroid function test results was $8.4 \%(n=$ 217). The results were analysed with reference to the clinical information on the request form and the thyroid hormone concentrations (table 1). Ninety three $(43 \%)$ of the patients with suppressed TSH concentrations had thyrotoxicosis either previously undiagnosed or treated. Sixty three $(29 \%)$ were receiving thyroid replacement treatment. A further $22(10 \%)$ had raised $T_{4}$ or raised $T_{3}$ concentrations. This group had a variety of clinical conditions and may have included patients receiving thyroxine replacement not indicated on the request form. The remaining 39 $(18 \%)$ of patients had serum $T_{4}$ and $T_{3}$ concentrations within the reference range and free $T_{4}$ concentration was normal in 26 out of 27 of these. Various clinical conditions were again described.

After this initial study 71 other patients with isolated undetectable serum TSH concentrations were

Table 1 Association of TSH $<0.2 \mathrm{mU} / \mathrm{l}$ with clinical condition as defined by information on request form

\begin{tabular}{|c|c|c|}
\hline Clinical condition & $(n=)$ & $\begin{array}{l}\text { Percentage } \\
\text { total }\end{array}$ \\
\hline $\begin{array}{l}\text { Previously undiagnosed thyrotoxic patients } \\
\text { Treated thyrotoxic patients } \\
\text { Patients receiving } \mathrm{T}_{4} \text { replacement } \\
\text { treatment }\end{array}$ & $\begin{array}{l}33 \\
60 \\
57\end{array}$ & $\begin{array}{l}15 \\
28 \\
26\end{array}$ \\
\hline $\begin{array}{l}\text { Patients receiving } T_{3} \text { replacement } \\
\text { treatment }\end{array}$ & 5 & $2 \cdot 3$ \\
\hline $\begin{array}{l}\text { Hypopituitary patients receiving } T_{4} \\
\text { replacement treatment } \\
\text { Others: }\end{array}$ & 1 & 0.5 \\
\hline $\begin{array}{l}\text { Raised } T_{4} \text { or raised } T_{3} \\
T_{4} \text { and } T_{3} \text { within reference range }\end{array}$ & $\begin{array}{l}22 \\
39\end{array}$ & $\begin{array}{l}10 \\
18\end{array}$ \\
\hline Total & 217 & 100 \\
\hline
\end{tabular}

randomly identified during routine reporting of the results over a period of one year, and follow up specimens and detailed clinical information were requested. This group included 10 men and 61 women (age range 19-96, median 73). Thirty four were outpatients and 37 inpatients at the time of the original specimen. According to the clinical information received, none of these patients had a history of thyroid disease.

Serum TSH concentration was measured by the RIAgnost IRMA kit in 55 specimens from the group of 71 patients. The RIAgnost kit method (detection limit $0.03 \mathrm{mU} / \mathrm{l}$ ) is more sensitive than the in-house IRMA method (detection limit $0 \cdot 12 \mathrm{mU} / \mathrm{l}$ ). TSH concentrations measured by the RIAgnost method in seven clinically and biochemically thyrotoxic patients were consistently lower than the detection limit of the assay. In the inpatient group 21 out of $28(75 \%)$ had detectable TSH concentrations in the RIAgnost assay (range $0.03-0.21 \mathrm{mU} / \mathrm{l}$ ), although the concentrations measured were below the lower limit of the reference range for this assay $(0.3 \mathrm{mU} / \mathrm{l})$. In the outpatient group TSH was detectable in 20 out of $27(74 \%)$ of the specimens (range 0.03-0.25 mU/1).

SHBG was measured in 50 specimens from the group of 71 patients. In the inpatient group the SHBG concentration was increased in three out of 29 patients and in two out of 21 patients in the outpatient group.

Thyroid antibodies were measured as an additional index of thyroid function in 49 patients. One inpatient had an antimicrosomal (titre $>1 / 100$ ) and antithyroglobulin antibodies present, and three outpatients were positive for antithyroid antibodies.

Fifty four repeat specimens (from 28 outpatients and 26 inpatients) were received two days -59 weeks after the original specimen. The TSH concentration (by in-house IRMA) remained persistently undetectable in $75 \%$ of outpatients and $54 \%$ of inpatients (table 2). Many different clinical conditions were described in this group, most patients having several concurrent clinical problems.

\section{Discussion}

The initial analysis of thyroid function test results

Table 2 Presence of persistently suppressed TSH concentrations in patients with undetectable TSH on initial testing

\begin{tabular}{|c|c|c|c|}
\hline Group & $(n=)$ & $\begin{array}{l}\text { No with } \\
\text { persistently } \\
\text { suppressed TSH } \\
\text { on second } \\
\text { measurement }\end{array}$ & $\begin{array}{l}\text { No with } \\
\text { measurable } \\
\text { TSH on second } \\
\text { measurement } \\
\text { (range } \text { mU/l) }\end{array}$ \\
\hline $\begin{array}{l}\text { Inpatients } \\
\text { Outpatients }\end{array}$ & $\begin{array}{l}26 \\
28\end{array}$ & $\begin{array}{l}14 \\
21\end{array}$ & $\begin{array}{c}12(0.23-5 \cdot 5) \\
7(0.2-12)\end{array}$ \\
\hline
\end{tabular}


suggested that thyrotoxicosis was not the major cause of undetectable serum TSH concentrations in specimens routinely sent to the laboratory. Only $43 \%$ of undetectable TSH concentrations were attributable to thyrotoxicosis either previously undiagnosed or treated. A further $29 \%$ of suppressed TSH concentrations were found in patients receiving thyroid hormone replacement treatment. Careful analysis of clinical data given is thus needed when interpreting serum TSH concentrations.

A group of 71 other patients having undetectable serum TSH concentrations associated with otherwise normal thyroid hormone concentrations were subsequently identified during routine reporting of results. From the clinical information given none of these patients had a history of thyroid disease nor had been given an iodide load, either in the form of radiographic contrast media or potassium iodide containing "cough medicines". The results of the measurement of SHBG concentration as a marker of peripheral thyroid hormone action suggested that $90 \%$ of the patients tested in the group did not have tissue responses typical of hyperthyroidism. Thyroid antibodies were also not detected in $92 \%$ of patients tested.

The data thus suggest that the finding of an isolated undetectable TSH concentration was not generally associated with hyperthyroidism in this group of both inpatients and outpatients.

Serum TSH concentration had returned to normal in a number of both outpatients and inpatients by the time that a second specimen was taken, although it remained persistently undetectable in other patients. In all patients thyroid hormone concentrations remained within the reference range. A large percentage of patients in the study was elderly but this may simply reflect the pattern of specimens sent to the laboratory. The current view is also that serum TSH concentration does not change with age in the absence of thyroid disease. ${ }^{14}$ Isolated undetectable TSH was not associated with any particular clinical condition.

To establish if the findings of the study were due to limitations in the sensitivity of the in-house TSH IRMA, specimens were also measured in the RIAgnost TSH kit which has a lower detection limit. Using this assay known hyperthyroid patients consistently had undetectable TSH concentrations. ${ }^{13}$ In this study $75 \%$ of the initial specimens had measurable $\mathrm{TSH}$ concentrations in the RIAgnost assay, although the concentrations were still below the lower limit of the reference range for the kit. The use of a more sensitive method for TSH may therefore decrease the number of patients who are classified as having an undetectable TSH concentration suggestive of thyrotoxicosis. Care would still be required in interpreting measurable TSH concentrations below the lower limit of the reference range. This finding is different from that of Spencer $e t$ $a l,{ }^{9}$ who concluded that their finding of patients with undetectable TSH concentrations in an unselected hospital population was not related to method.

Several studies have now suggested that serum TSH may be suppressed in severe illness, particularly in patients receiving treatment with glucocorticoids and dopamine.$^{81516}$ Spencer $e t$ al have shown that in a large series of unselected admissions to an acute medical unit an undetectable serum TSH was three times more likely to be due to non-thyroidal illness than hyperthyroidism. ${ }^{9}$

This study has shown that TSH may also be suppressed in patients who are attending hospital as outpatients but who may have several clinical problems. Undetectable serum TSH associated with $T_{4}, T_{3}$, and free $T_{4}$ concentrations within the reference range is not therefore diagnostic of hyperthyroidism in either inpatients or outpatients, a view supported by measurement of other indices of thyroid function, such as detection of antithyroid antibodies and SHBG concentration.

Monoclonal antibodies to TSH were kindly donated by Dr K Siddle, Addenbrooke's Hospital, Cambridge. We are grateful to the staff of the Endocrine Section, department of clinical biochemistry, Hope Hospital, for performing the routine TSH, $T_{4}, T_{3}$ and free $T_{4}$ measurements.

\section{References}

1 Woodhead JS, Weeks I. Circulating thyrotrophin as an index of thyroid function. Ann Clin Biochem 1985;22:455-9.

2 Seth J, Kellett HA, Caldwell G, et al. A sensitive immunoradiometric assay for serum thyroid stimulating hormone: a replacement for the thyrotrophin releasing hormone test. $\mathrm{Br}$ Med J 1984;289:1334-6.

3 John R, Jones MK. An automated immunoradiometric assay for human thyrotrophin. Clin Chem 1984;30:1396-8.

4 Cobb WE, Lamberton RP, Jackson IDD. Use of a rapid sensitive immunoradiometric assay for thyrotrophin to distinguish normal from euthyroid subjects. Clin Chem 1984;30:1558-60.

5 Pekary AE, Hershman JM. A new monoclonal antibody two site solid phase immunoradiometric assay for human thyrotrophin evaluated. Clin Chem 1984;30:1213-5.

6 Caldwell G, Kellett HA, Gow SM, et al. A new strategy for thyroid-function testing. Lancet 1985;i:1117-9.

7 Davies AB, Williams I, John R, et al. Diagnostic value of thyrotrophin releasing hormone tests in elderly patients with atrial fibrillation. $\mathrm{Br}$ Med J 1985;291:773-6.

8 Dubuis JM, Burger AG. Thyroid stimulating hormone measurements by immunoradiometric assay in severely ill patients. Lancet 1986;ii:1036-7.

9 Spencer C, Eigen A, Shen D, et al. Specificity of sensitive assays of thyrotrophin (TSH) used to screen for thyroid disease in hospitalised patients. Clin Chem 1987;33:1391-6.

10 Mortimer CH, Anderson DC, Liendo-Ch P, et al. Thyrotoxicosis: relations between clinical state and biochemical changes during carbimazole treatment. Br Med J 1977;i:138-41. 
11 Cooper DS, Ladensen BW, Nisula BC, et al. Familial thyroid hormone resistance. Metabolism 1982;31:504-9.

12 Fraser CG, Wilde CE. Statistical analysis of reagent kit evaluation data. Commun Lab Med 1986;2:1-5.

13 Swift AD, Bruce SE, Ratcliffe JG. Comparative evaluation of high sensitivity thyroid stimulating hormone assay kits. London: DHSS Scientific and Technical Branch, 1986.

14 Raggatt PR, Burrin JM, Beastall GH, et al. Thyrotrophin (TSH): A review of performance and interpretation of clinical serum TSH assays in the UK. Reports of a Task Force set up by the Analytical Methods Working Party of the ACB Scientific Committee, 1985. London: ACB, 1985.
15 Wehmann RE, Grogerman RI, Burns WH, et al. Suppression of thyrotrophin in the low thyroxine state of severe non-thyroidal illness. N Engl J Med 1985;312:546-52.

16 Ratnaike S, Goodwin M, Dean D. Anomalous thyrotrophin values. Clin Chem 1987;33:1213-4.

Requests for reprints to: Dr M A Pollock, Department of Clinical Biochemistry, Hope Hospital, Eccles Old Road, Salford M6 8HD, England.

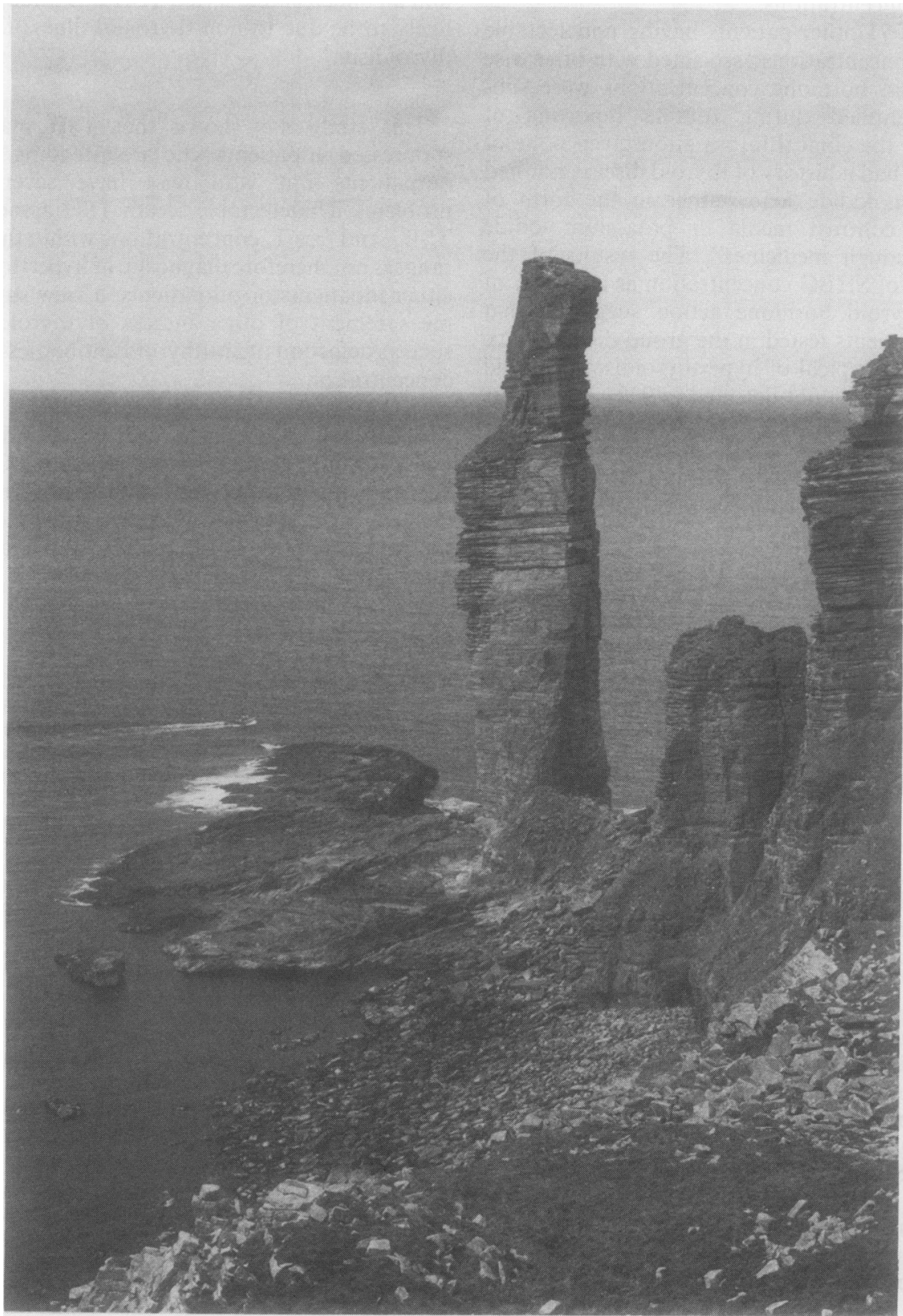

The Old Man of Hoy, Orkeney, taken by Walter Timperley. 